\title{
Diagnostik Angiografi dan Intervensi Non-Invasif pada Tetralogy of Fallot (TOF)
}

\author{
Radityo Prakoso, Danayu Sanni Prahasti
}

$L$

a Maladie Bleue yang dideskripsikan oleh Louis Arthur Etienne Fallot pada tahun 1888, merupakan gambaran klinis dari fisiologi yang disebabkan malformasi anatomis Penyakit Jantung Bawaan (PJB) yang saat ini disebut dengan Tetralogy of Fallot (TOF). ${ }^{1}$ Gambaran utama kelainan ini terdiri dari hubungan interventrikular atau ventricular septal defect, hubungan biventrikular dari cabang aorta yang menaiki otot septum ventrikel, obstruksi aliran ventrikel kanan, dan hipertrofi ventrikel kanan. Tiap komponen mempunyai derajat keparahan yang bervariasi, dan mempengaruhi manifestasi klinis dan tatalaksana penyakit tersebut. ${ }^{1,2}$ Perkembangan tatalaksana TOF dari paliatif menjadi bedah korektif pada balita dan anak-anak diikuti dengan berkembangnya peran intervensi transkateter. ${ }^{4}$

Diagnostik angiografi pada pasien TOF ditujukan untuk pencitraan arteri koroner abnormal atau anatomi PA perifer, serta tekanan di ruang-ruang jantung. Selama bertahun-bertahun, kateterisasi merupakan hal yang wajib dilakukan untuk evaluasi TOF sebelum operasi, yang prinsipnya ialah untuk mendokumentasikan anatomi pulmonal, anatomi koroner, dan adanya tambahan VSD. Angiography dilakukan menggunakan injeksi kontras di ventrikel kanan, arteri pulmonal, ventrikel kiri, dan aorta sesuai

\section{Corresponding Address:}

dr. Radityo Prakoso, SpJP, Divisi Aritmia, Departemen Kardiologi dan Kedokteran Vaskuler FKUI dan Pusat Jantung Nasional Harapan, Kita, JI S Parman Kav 87 Jakarta I I420, E-mail: karajanh70@gmail.com kebutuhan, pada proyeksi yang sesuai dengan bentuk anatomis termasuk aliran ventrikel kanan, arteri pulmonal, tambahan VSD potensial dan arteri koroner. ${ }^{2}$ Penilaian angiocardiographic pasien dengan TOF meliputi injeksi ventrikel kiri dan kanan, injeksi aorta, dan injeksi arteri pulmonal atau arteri koroner.

Gambaran anatomi arteri pulmonal dan tekanan ruang-ruang jantung penting untuk pasien yang menjalani tindakan paliatif pirai aortapulmonal. Pada kasus ini, arteri pulmonal dapat masuk secara retrograde melalui pirai. Angiography sebaiknya dapat diarahkan untuk mengidentifikasi stenosis arterial, termasuk yang timbul karena penyimpangan bedah. Sudut kamera kranial, pada proyeksi oblik kanan atau kiri, dapat menggambarkan area obstruksi arterial proksimal yang tidak dapat dilihat dengan baik pada injeksi ventrikular. Gambaran anatomi arteri koroner dapat dijangkau oleh angiography aorta, injeksi arteri koroner selektif, atau kombinasi keduanya. Injeksi aorta, pada proyeksi oblik anterior kanan dan kiri dapat menunjukkan gambaran yang adekuat. Tambahan informasi dapat didapat melalui anatomi arkus aorta dan anatomi pembuluh darah brachiocephalic. Bila anatomi masih tidak jelas dengan aortography, maka injeksi arteri koroner dapat dilakukan untuk menggambarkan anatomi arterial. Gambaran kolateral aortapulmonal juga merupakan tujuan rutin tindakan kateterisasi. Aortography sebaiknya dapat menggambarkan berbagai pembuluh darah kolateral, yang biasanya berasal dari aorta desenden. Pada beberapa kasus, terutama pada atresi pulmonal dan VSD, tambahan pembuluh darah 
dapat berasal dari pembuluh darah brachiocephalic. Diindikasikan injeksi selektif ke dalam pembuluh darah tersebut. ${ }^{5}$

Terdapat beberapa intervensi paliatif transkateter yang dapat dilakukan pada masa neonatal untuk meningkatkan saturasi oksigen dan pertumbuhan arteri pulmonal sampai bedah korektif dapat dilakukan. Pada kebanyakan pasien dapat timbul stenosis cabang arteri pulmonal, obstruksi aliran ventrikel kanan, insufisiensi pulmonal, atau sisa pirai kiri-kanan signifikan selama masa followup setelah bedah korektif. Intervensi transkateter dapat dilakukan untuk mengatasi masalah tersebut, bahkan dapat mengurangi kebutuhan untuk operasi. ${ }^{6,7}$

Karl, dkk menggunakan protokol koreksi pada bayi dan neonatus dengan TOF duktus dependen dan bukan duktus dependen. Ductus yang dimaksud disini adalah Patent Ductus Arteriosus (PDA), dimana pada varian TOF yang berat, merupakan penyokong aliran ke paru, yang mempertahankan nyawa pasien. Dalam protokol ini disebutkan pasien akan menjalani koreksi elektif di usia 2-4 bulan, atau lebih cepat jika diindikasikan. Ductus stenting, atau trans-sternal modified Blalock Taussig shunt (MBTS) dapat dilakukan pada kasus tertentu. ${ }^{3}$

Kebanyakan prosedur intervensional, ketika diterapkan pada pasien dengan TOF, dilakukan atas dua indikasi umum: meringankan obstruksi pulmonal dan embolisasi pada berbagai level dan menggandakan sumber aliran darah pulmonal. Indikasi untuk intervensi dengan kateterisasi ditentukan oleh klinisi dan institusi dengan menimbang antara risiko dan keuntungan dibandingkan dengan intervensi bedah. Sideris et al meneliti keamanan dan efikasi koreksi perkutaneus total pada TOF varian dengan dominan stenosis katup pulmonal. Penelitian tersebut menunjukkan hasil yang baik secara signifikan, namun masih perlu dilakukan percobaan klinis lainnya untuk menilai efektivitas dan keamanan tindakan tersebut. ${ }^{4}$

Ductus stenting adalah alternatif menarik dari pembedahan shunt konvensional pada PJB duktus dependent. Dengan perkembangan stent koroner yang memiliki profil lebih baik, fleksibel dan dapat dilacak, stenting mungkin lebih aman dan lebih mudah dari sebelumnya. Tidak seperti PDA sebagai lesi terisolasi, maka PDA pada PJB sianotik memiliki variabilitas anatomi yang luas. Duktus cenderung berasal lebih proksimal dari arkus aorta, atau arteri subclavia. Ductus juga cenderung lebih berkelokkelok, panjang, sehingga stenting secara teknis tidak mungkin dilakukan. Peran angiografi diperlukan untuk mengevaluasi detail morfologi PDA. Komplikasi yang mungkin terjadi saat stenting antara lain akut trombosis, spasme duktus, migrasi dari stent yang telah terkembang. Kunci dari kesuksesan prosedur adalah pemilihan kasus dan teknik yang digunakan. ${ }^{6}$

Pasien dengan TOF mempunyai tanda dan gejala yang bervariasi tergantung pada derajat keparahan Right Ventricular Outflow Tract Obstruction (RVOTO). Pasien dengan obstruksi pirai kanan-kiri berat biasanya datang dengan gejala klinis sianotik saat lahir. ${ }^{5}$ Gejala ini paling sering timbul pada pasien TOF dengan atresi pulmonal yang merupakan salah satu kasus duct-dependent. Selain pemberian infus prostaglandin E1 dan Blalock-Taussig shunt, PDA stenting merupakan salah satu upaya untuk mempertahankan patensi duktus. ${ }^{6}$ Penelitian yang dilakukan oleh Vida dkk pada tahun 2010, menyimpulkan bahwa pada operasi pasien setelah PDA stent pada sirkulasi pulmoner duktus dependen ialah aman dan memiliki resiko rendah. Adanya PDA stenting membutuhkan maneuver bedah tambahan di arteri pulmoner pada setengah populasi penelitian, dan intervensi post operatif kadang-kadang dibutuhkan. ${ }^{8}$ PDA stenting juga merupakan pilihan terapi paliatif pada pasien dengan berat lahir rendah dan prematur, yang termasuk dalam risiko tinggi pembedahan. ${ }^{9}$ Tindakan ini tidak invasif dan dapat sekaligus menghindari distorsi pulmonal dan ketidakseimbangan perfusi paru akibat komplikasi pembedahan. ${ }^{9}$

Salah satu bentuk spesial dari TOF, ialah adanya hipoplasia arteri pulmonal, right ventricle outflow tract (RVOT) dan adanya arteri kolateral (MAPCA). Pada pasien tersebut, terutama apabila kondisi anatomis tidak memungkinkan untuk tindakan bedah, maka pemasangan stent pada RVOT dan arteri pulmonal merupakan salah satu alternatif. Prosedur ini dapat juga diterapkan pada pasien dengan arteri pulmonal yang tidak berkembang dengan baik dan merupakan alternatif yang lebih baik daripada Blalock-Taussig shunt. Hal ini dapat meningkatkan aliran darah pulmonal, saturasi darah dan peningkatan kondisi klinis. ${ }^{10}$ Selain itu, pada pasien bayi prematur dengan berat badan lahir rendah, RVOT stenting juga merupakan alternatif tindakan non-invasif yang lebih dipilih dibandingkan dengan pembedahan. ${ }^{10}$ Pada penelitian yang dilakukan oleh Bang $S \mathrm{dkk}$, RVOT stenting dilakukan pada pasien yang tidak mencapai berat optimal untuk prosedur operasi. Pilihan terapi paliatif untuk TOF yang dapat meningkatkan pirai arteri pulmonal termasuk Blalock-Taussig shunt, PDA stenting, ballon pulmonary valvuloplasty, dan RVOT 
stenting. Blalock - Taussig shunt dapat memberikan komplikasi berupa hipoplasia arteri pulmonal dan distorsi pulmonal. Oleh karena itu, diperlukan pertimbangan yang matang untuk melakukan prosedur pembedahan tersebut. Namun, pada RVOT stenting, diameter RVOT merupakan hal yang perlu dinilai lebih awal. Diameter RVOT yang disarankan ialah 1-2 $\mathrm{mm}$ lebih besar dari diameter infundibular selama fase diastol, dan diameter minimal stent yang digunakan ialah $4 \mathrm{~mm} .{ }^{11}$ Peningkatan pada aliran antegrade dapat meningkatkan pertumbuhan arteri pulmonal dengan meningkatkan aliran darah pulmonal. Indikasi paliatif pada keadaan ini ialah dengan mempertimbangkan bahwa intervensi bedah definitif dapat dilakukan lebih aman pada usia yang lebih dewasa. Pendekatan ini mencegah komplikasi bedah yang mungkin terjadi dan atau distorsi arteri pulmonal yang dapat terjadi pada Modified Blalock-Taussig shunt (MBTS). ${ }^{4}$

Coil embolisasi pada arteri kolateral aortapulmonal juga merupakan salah satu intervensi yang tepat sebelum koreksi secara pembedahan. Coiling pembuluh darah yang mengaliri segmen pulmonal dan telah disuplai oleh aliran arteri pulmonal dapat digunakan untuk mengurangi pengisian volume ventrikel kiri dan untuk mengeliminasi limpahan ke pembuluh kapiler arteri pulmonal selama bypass kardiopulmonal. ${ }^{3}$ Pada keadaan postoperatif, peran kateterisasi intervensi berupa balloon angioplasty yang meliputi pemotongan balon dan stenting dapat memberikan gambaran obstruksi sisa arteri pulmonal, terutama obstruksi distal yang tidak dapat dijangkau sternotomi. Pemasangan stent intra arterial dapat digunakan ketika angioplasty sederhana memberikan pembebasan inadekuat. Hal ini disebabkan recoil pembuluh darah yang menghalangi pembebasan stenosis dengan angioplasty. ${ }^{5,2}$

\section{Aknowledgement}

Dr Sabrina Erriyanti

\section{Daftar Pustaka}

1. Bailliard F, Anderson R. Tetralogy of Fallot. Orphanet Journal of Rare Diseases 2009; 4: 2.

2. Keane JF, Lock JE, . FD. Nadas' Pediatric Cardiology. 2 ed. Philadelphia: Elsevier; 2006.

3. Karl TR. Tetralogy of fallot: a surgical perspective. The Korean journal of thoracic and cardiovascular surgery 2012;45:21324.

4. Sideris EB, Macuil B, Justiniano S, PS. R. Total percutaneous correction of a tetralogy of Fallot variant with dominant pulmonary valve stenosis. Heart 2005; 91:345-7.

5. Allen HD, Driscoll DJ, Shaddy RE, TF. F. Moss and Adams' Heart Disease in Infants, Children, and Adolescents including the fetus and young adult. 7th ed: Lippincott Williams and Wilkins; 2008.

6. Alwi M. Stenting the ductus arteriosus: Case selection, technique and possible complications. Ann Pediatr Cardiol 2008;1(1):3845.

7. Gary E, Stapleton. The role of cardiac catheterisation in patients with tetralogy of Fallot Cardiology in the Young 2013;23:8837.

8. Vida VL, Speggiorin S, Maschictto N, Padalino MA, Tessari C, Biffanti R, Cerutti A, Milanesi O, Stellin G. Cardiac operations after patent ductus arteriosus stenting in ductdependent pulmonary circulation. Ann Thorac Surg. 2010; 90(2): 605-9

9. Santoro G, Bigazzi MC, Palladino MT, Russo MG, Carrozza M, Calabro R. Transcatheter palliation of tetralogy of fallot with pulmonary artery discontinuity. Texas Heart Institute Journal. 2005; 32 (1): 102-4

10. Dryzek P, Mazurek-Kula A, Moszura T, Sysa A. Right ventricle outflow tract stenting as a method of palliative treatment of severe tetralogy of Fallot. Cardiology Journal. 2008; 15(4): 376-9

11. Bang S, Ki Ko H, Yu JJ, Han MK, Kim YH, and Ko IK, et al. Right ventricular outflow tract stenting in a low birth weight infant born with Tetralogy of Fallot and prostaglandin E1 dependency. Korean Circ J. 2011; 41: 744-74 